\title{
RELATIONSHIP BETWEEN BIOGAS PRODUCTION AND VARIATIONS IN ELECTRIC RESISTIVITY IN LANDFILL OF RIO CLARO CITY, BRAZIL
}

\author{
César Augusto Moreira ${ }^{1}$, Marcus Cesar Avezum Alves de Castro ${ }^{1}$, Leonardo Paioli Carrazza ${ }^{1}$, \\ Fernanda Cavallari², Lívia Portes Innocente Helene ${ }^{2}$ and Fabio Braz Machado ${ }^{3}$
}

\begin{abstract}
This work relates measures of the biogas flow in drains located on landfill with measurements of electric resistivity, obtained by the technique of geophysical logging by measuring cable installed in two vertical boreholes near to two biogas drains, with different flows. The results indicate that variation in rainfall, generation and accumulation of biogas in landfill, are repairable correlation with oscillations in electrical resistivity measures. The biogas production is apparently conditioned by age of residues and organic matter available from the degradation. The biogas drain in region with low production of biogas does not present resistivity pattern directly or indirectly correlated to biogas production, while the biogas drain in region with high gas production was characterized by high resistivity values, with seasonal variation by influence of rainfall.
\end{abstract}

Keywords: methane, organic matter, rainfall, DC resistivity, logging.

RESUMO. Este trabalho relaciona medidas da vazão de biogás, em drenos localizados em aterro sanitário, com medidas de resistividade elétrica, obtida pela técnica de perfilagem geofísica por meio de cabos instalados próximos a dois drenos de biogás com diferentes vazões. Os resultados indicaram que variações de pluviosidade, geração e acumulação de biogás no aterro são passíveis de correlação com oscilações em medidas de resistividade elétrica. A produção de biogás é aparentemente condicionada à idade dos resíduos e à disponibilidade de matéria orgânica passível de degradação. 0 dreno de baixa vazão não apresentou um padrão de resistividade direta ou indiretamente correlacionável com a produção de biogás. A região do dreno de alta vazão foi caracterizada por alta resistividade, com variações sazonais por influencia de chuvas.

Palavras-chave: metano, matéria orgânica, chuva, eletrorresistividade, perfilagem.

\footnotetext{
1 Universidade Estadual Paulista - UNESP, Applied Geology Department, Geoscience and Exact Science Institute, Rio Claro Campus, Avenida 24-A, 1515, P.0. Box 178, 13506-900 São Paulo, SP, Brazil. Phone: +55(19) 3526-2819 - E-mail: moreirac@rc.unesp.br; mccastro@rc.unesp.br; leopcarrazza@hotmail.com 2 Universidade Estadual Paulista - UNESP, Geoscience and Environmental Science Post-graduation Program, Geoscience and Exact Science Institute, Rio Claro Campus, Avenida 24-A, 1515, P.0. Box 178, 13506-900 São Paulo, SP, Brazil. Phone: +55(19) 3526-2819 - E-mails: fee.cavallari@gmail.com; liviapihelene@gmail.com 3 Universidade Federal de São Paulo - UNIFESP, Exact Science and the Earth Department, Diadema Campus, Rua Antônio Doll de Moraes, 105, 09920-540 São Paulo, SP, Brazil. Phone: +55(19) 9935-1049 - E-mail: fabiobrazmachado@gmail.com
} 


\section{INTRODUCTION}

The adaptation of methods and techniques of research in Geoscience area is somewhat growing in face of the diversity of objects of study and subareas that have emerged in recent years.

Geophysics is a science that studies geologic materials, structures and layers, being them constituents of the Earth or other planets, through the analysis of intrinsic physical parameters such as density, radioactivity, magnetization, beside others, using tools that allow for indirect measures and that enable investigations ranging from centimeters to hundreds of meters deep (Milsom \& Eriksen, 2011).

Logging is an area of geophysics applied in data acquisition and analysis of physical properties on exploratory wells or holes through similar instrument to that used in land acquisitions, though with reading sensors adapted for drilling (Ellis \& Singer, 2008).

It has applications in hydrogeological and environmental studies, but with large-scale use in hydrocarbon exploration. Physical parameters measures such as electric resistivity and natural electrical potential are part of routine investigations on exploratory holes or for detailing in oil fields, due to the possibility of estimating lithological parameters as permeability, porosity, grain size, types of rocks, among others (Asquith \& Gibson, 1982).

The DC Resistivity method is an established and frequently applied tool in environmental studies, which consists in the artificial generation of electric currents that are introduced into the soil, for measuring the resulting potential differences. Deviations from the potential differences standard provide information about shape and electrical properties of subsurface heterogeneities (Keary et al., 2002; Telford et al., 2004).

This method is widely used in studies of environmental diagnosis, in cases such as investigations of contaminants in soil and groundwater from landfills (Mota et al., 2004; Georgaki et al., 2008; Belmonte-Jiménez et al., 2012; Moreira et al., 2013; Moreira et al., 2014; Omolayo \& Tope, 2014). The characteristic signature of liquid contaminants enriched in salts like the leachate arising from the decomposition of organic waste is the low electric resistivity.

Although there are, many studies that describe the use of geophysical methods in environmental diagnosis of landfills, most of these works mainly focus essentially the characterization of the area with percolation of leachate. However, there are few studies aimed at determining relationships between electric resistivity, natural electrical potential and biological and physicochemical processes and their relationship to the production of biogas and leachate in landfills (Georgaki et al., 2008; Rosqvist et al., 2011; Moreira et al., 2013).
This work proposes the development of a static system of geophysical logging in the municipal landfill of Rio Claro (Brazil), in an attempt to assess the relationship between changes in physical parameters of electric resistivity and biogas flow in drains nearby, during 1 year of the monitoring.

\section{STUDY AREA}

The study area is located in the municipality of Rio Claro, State of São Paulo, with main access through the Cornelio Pires Highway (SP-127), which makes the link between the cities of Rio Claro and Piracicaba (Fig. 1). The landfill receives an average of 4,000 tons of domestic solid waste per month, has an area of 142 thousand square meters and has been active since 2001.

The geological context of the study area is represented by sedimentary rock gathered in Corumbataí and Rio Claro Formations (Moreira et al., 2014). The Corumbataí Formation is characterized by mudstones, siltstones and purplish and redish-brown shales, sometimes greenish, with interbedded sandstones, carbonate beds and coquine. The Rio Claro Formation is represented by fine to medium sandstones with varied coloration, such as whitish, yellowish, reddish and purplish.

\section{MATERIALS AND METHODS}

The procedure for data acquisition was started from the selection of two gas drains that present different characteristics due to the age of deposition of waste, described in detail in Antonio (2012). The drain 5 crosses oldest wastes (10 years), whose basal portion goes back to the beginning of the operation of the landfill, while the drain 28 is located in a region with residues released a few years ago (2 years) and reached maximum capacity receive materials.

Later, measurements of flow and composition of the gases emanating from these two ducts were performed, by means of the equipment Lantec GEM-2000, which allows the measurement of concentrations of $\mathrm{CO}_{2}, \mathrm{CH}_{4}$ and $\mathrm{O}_{2}$ and temperature (Antonio, 2012). The biogas flow was measured with the aid of a thermoanemometer inserted into each drain.

Near the selected ducts, was performed vertical drilling for cables installation, made with graphite sensors, distributed in constant spacing of $40 \mathrm{~cm}$ (Fig. 2). The cables were introduced into the holes immediately after removal of the drill bit, with the aid of wooden strips. Due to the low cohesion of the waste, the holes were closed spontaneously, a few hours after installation of the cables.

The technique of geophysical logging for reading the electric resistivity parameter, with movement of reading points with 


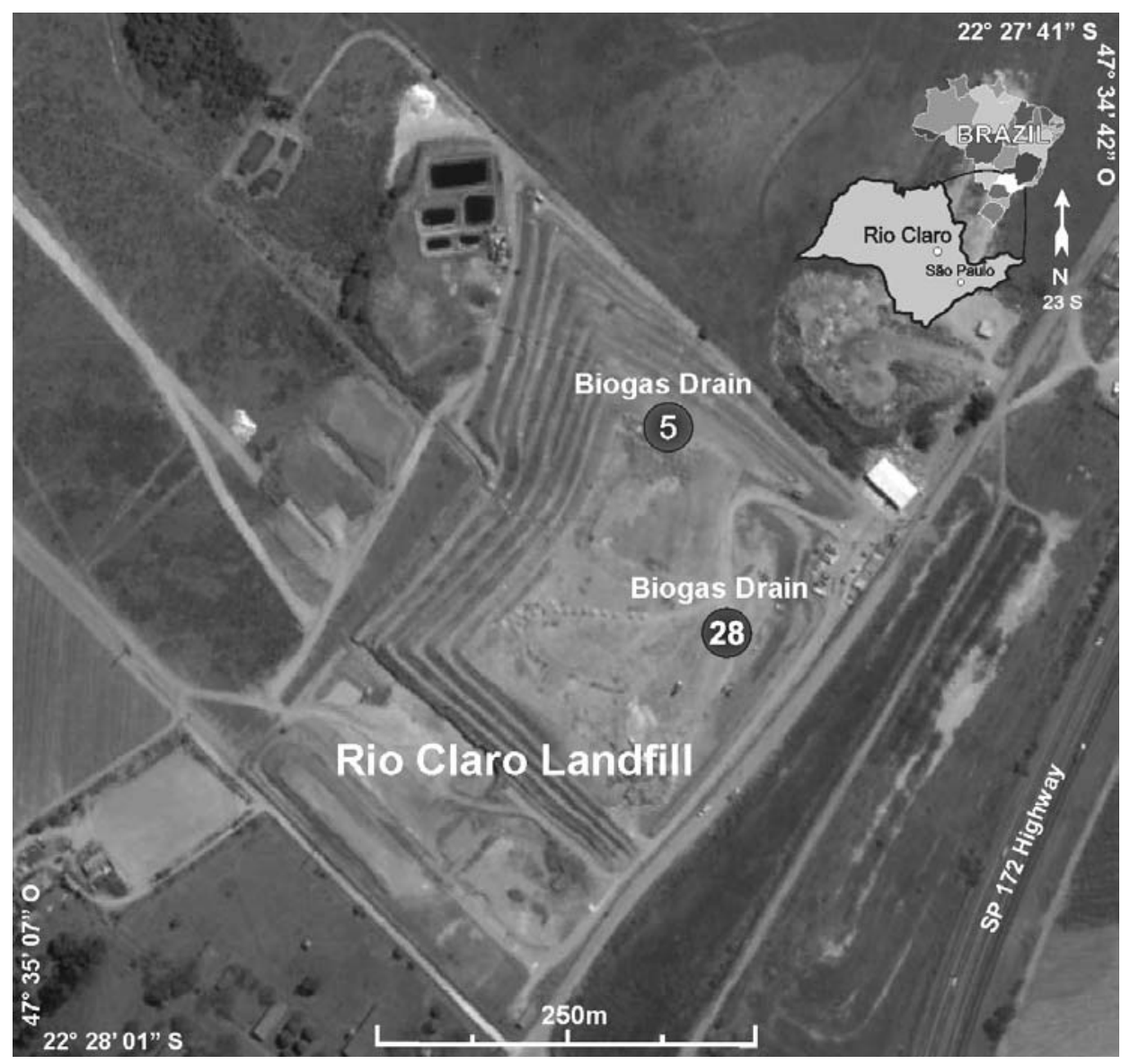

Figure 1 - Study area, with localization of biogas drain.

depth was used Wenner array and only one measurement for each $40 \mathrm{~cm}$ of depth. The Terrameter SAS 4000 resistivity meter, which enables readings of electric resistivity, chargeability and natural electric potential, through periodic cycles of reading on programmed time intervals was used (ABEM, 2009).

The DC Resistivity method is based on the propagation of subsurface electric field generated artificially by injecting electric current $(I)$ from electrode devices. The electric potential $(\Delta V)$ produced by the passage of this field in the subsurface is captured by a receiving circuit and measured by means of a voltmeter. Applying Ohm's Law considering the spacing between electrodes, represented by a factor called $K$, allows measurements of apparent resistivity parameter $\left(\rho_{a}\right)$ for various levels of depth (Eq. 1).

$$
\rho_{a}=K \frac{\Delta V}{I} \Omega . m
$$

The resistivity parameter depends on the nature and the physical state of the material analyzed. The resistivity and electric conductivity are related to the mechanisms of propagation of electric current of the materials, conditioned in geological material to processes of electronic or electrolytic conductivity (Keller \& Frischknecht, 1966). The first is associated to the presence of metallic or conductor minerals, while the second occurs due to movement of ions dissolved in the water contained in the pores or cracks.

As groundwater often contains dissolved ions, the process of electrolytic conductivity is predominant in the geological environment. Similarly, the leachate from decomposition of organic waste is characterized by high amounts of total dissolved solids (Meju, 2000). This electrolyte solution features a behavior similar to that of groundwater regarding the transit of electric current, i.e., consists of a low electric resistivity material.

\section{RESULTS AND DISCUSSION}

The integrated analysis this result enables for some important considerations about the action of anaerobic degradation processes of organic matter and their effects on the change in physical properties in the interval unsaturated with leachate. 

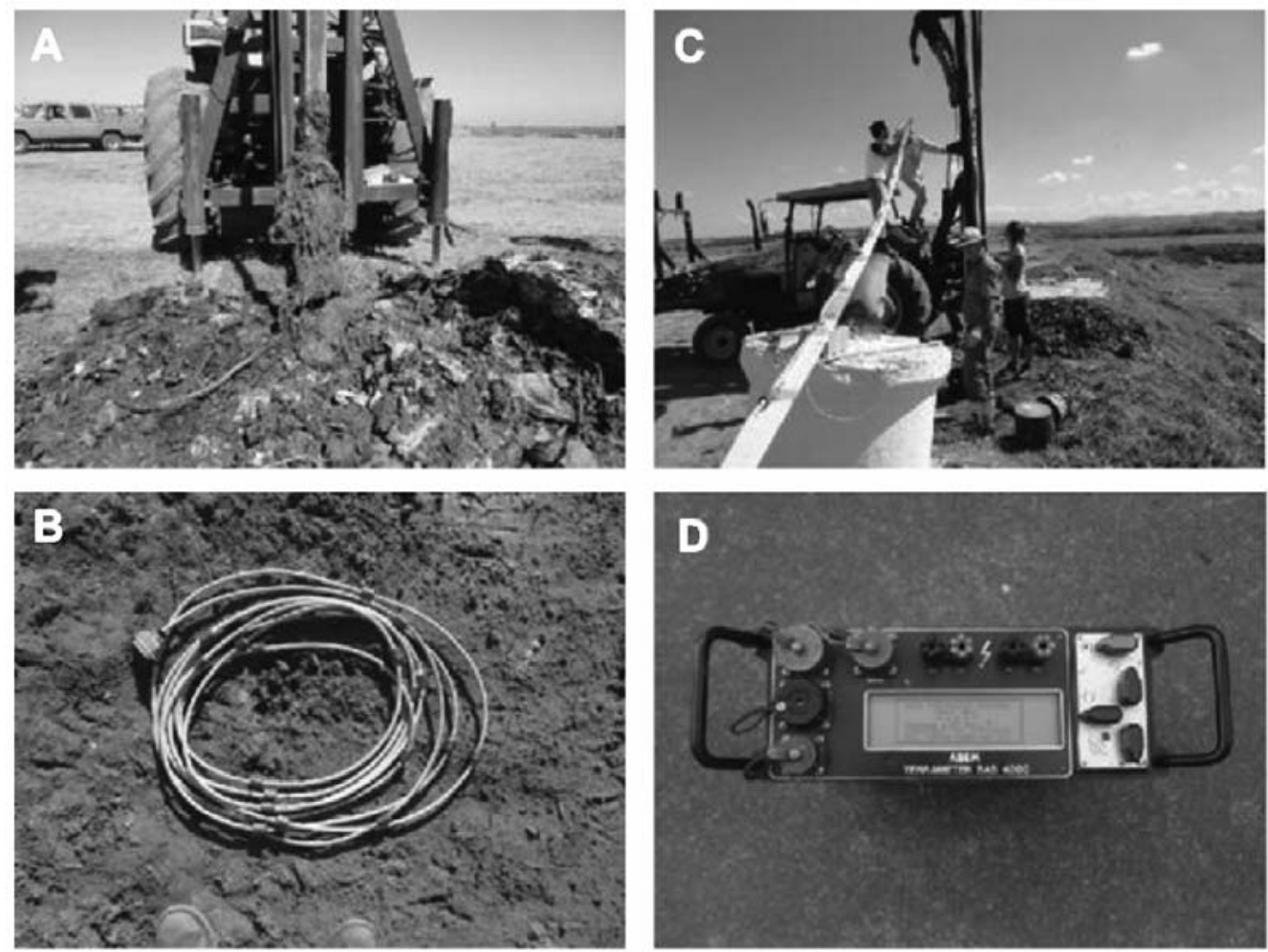

Figure 2 - A) Pit drilling; B) Cable for natural electrical potential measurement; C) Installation procedure; D) Terrameter SAS 4000.

Biogeochemical reactions are initiated immediately after coverage of waste in landfills. Organic compounds are oxidized in aerobic processes in shallow locations where aeration occurs by contribution of atmospheric oxygen or infiltration of rainwater, in reactions similar to combustion, generating $\mathrm{CO}_{2}$ and water vapor.

However, the effect of chemical and biological processes is accentuated by anaerobic digestion in three main stages (Christensen et al., 1994; Themelis \& Ulloa, 2007).

At first, hydrolysis of complex organic matter occurs by the action of fermentative bacteria in soluble molecules. Then, these molecules are converted into simple organic acids such as acetic acid, propionic acid, butyric acid and ethanol, plus $\mathrm{CO}_{2}$ and $\mathrm{H}_{2}$. In the third stage, the generation of $\mathrm{CH}_{4}$ by methanogenic bacteria occurs, by breaking of acids in $\mathrm{CH}_{4}$ and $\mathrm{CO}_{2}$ or by the reduction of $\mathrm{CO}_{2}$ and $\mathrm{H}_{2}$ (Eqs. 2, 3 and 4).

$$
\begin{gathered}
\text { (Acetogenesis) } \\
\mathrm{C}_{6} \mathrm{H}_{12} \mathrm{O}_{6} \leftarrow 2 \mathrm{C}_{2} \mathrm{H}_{5} \mathrm{OH}+2 \mathrm{CO}_{2} \\
\text { (Methanogenesis) } \\
\mathrm{CH}_{3} \mathrm{COOH} \leftarrow \mathrm{CH}_{4}+\mathrm{CO}_{2} \\
\mathrm{CO}_{2}+4 \mathrm{H}_{2} \leftarrow \mathrm{CH}_{4}+2 \mathrm{H}_{2} \mathrm{O}
\end{gathered}
$$

The maximum amount of biogas that can be produced by the anaerobic decomposition may be determined approximately by (Eq. 5).

$$
\mathrm{C}_{6} \mathrm{H}_{10} \mathrm{O}_{4}+1,5 \mathrm{H}_{2} \mathrm{O} \leftarrow 3,25 \mathrm{CH}_{4}+2,75 \mathrm{CO}_{2}
$$

This exothermic reaction releases a small amount of heat and produces a gas at levels ranging from $54 \% \mathrm{CH}_{4}$ and $46 \% \mathrm{CO}_{2}$. The biogas produced in landfills also contains water vapor near the saturation point, besides small amounts of $\mathrm{NH}_{4}, \mathrm{H}_{2}, \mathrm{H}_{2} \mathrm{~S}$ and other minor constituents (Farquhar \& Rovers, 1973).

There are many factors to be met in order to have continuity of the anaerobic process. However, it is essential that there is a constant supply of the main reactant involved in the process, i.e. water (Christensen et al., 1994; Themelis \& Ulloa, 2007). The mass balance between the organic compound and water in Equation 4 indicates that $1 \mathrm{~kg}$ of water enables consumption of $5.4 \mathrm{~kg}$ of organic matter.

The drains evaluated in the Rio Claro landfill are distant from each other about $200 \mathrm{~m}$, consisting of residues from the same city, subject to the same processes of release, compaction and covering material, and subjected to the same amount of rainfall.

Therefore, differences in gas flow between the drains are 
attributable to the amount of organic matter available for anaerobic reactions. The drain region 28 had received the last layer of waste three months from the start of the study, in contrast to the drain region 28, where the last layer of waste dates of 5 years before the studies began. In this sense, the flow of biogas comparatively higher in the drain 28 can be attributed to the age of the waste and the availability of organic matter able to degradation.

The variation in the intensity of the decomposition process of organic waste is reflected in the biogas flow and apparently causes significant changes in physical properties as the electrical resistivity.

The electrical resistivity data were collected fortnightly and tabulated, allowing for the plotting of graphics with the measure of natural electrical potential every $40 \mathrm{~cm}$ from the surface up to a depth of $5 \mathrm{~m}$ (Fig. 3).

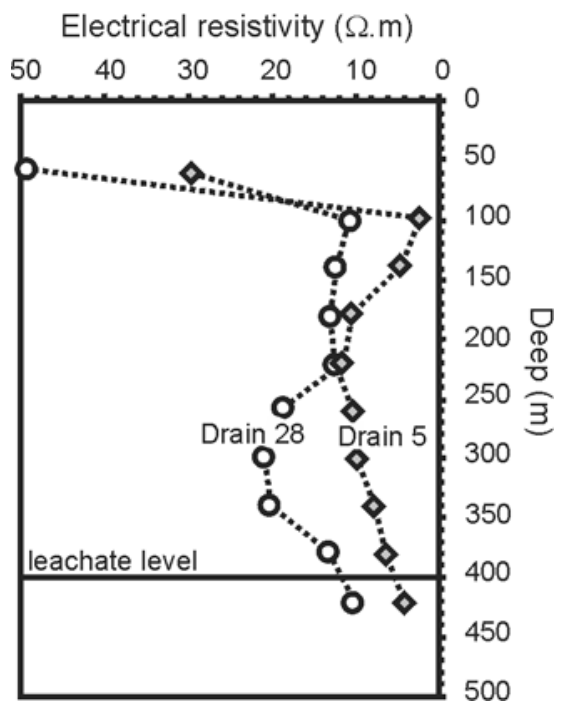

Figure 3 - Measurements of electrical resistivity (in $\Omega . m$ ) for the first day (May/2011), with position of leachate level, to the drains 5 and 28.

Measurements of biogas flow acquired fortnightly and described in detail in Antonio (2012), are presented graphically in conjunction with rainfall measurements acquired on the same days, both for the 1-year period (May 2012 to May 2013). From the selection of electrical resistivity measurements at $300 \mathrm{~cm}$ depth, charts of annual variation, integrated to the rainfall for the period were prepared (Fig. 4).

This depth is selected due to great variation in electrical resistivity, besides to the position in maximum reduction conditions in aeration zone. The measure next to drain 5 presents annual variation between $2 \Omega$.m and $135 \Omega$.m.

The first 50 days are characterized by resistivity values around $25 \Omega . m$, in a context of high rainfall and constant biogas flow. The reduction in rainfall is followed by an increase in resistivity values up to a maximum of $145 \Omega . \mathrm{m}$ in 80 days from the start in readings, possibly related to the reduction in humidity in the residues of the aerated zone of the profile, followed by reduction in biogas flow.

From 100 days on, there occurs a steep decline in resistivity values concurring with an increase in pluviosity, possibly due to the increase in humidity in the residues of the aerated zone, in the area with fractured covering soil, due age of deposits. On the 150th day, the resistivity undergoes a brief increase followed by gradual decay to values near zero after 250 days, until the end of the monitoring period, coinciding with periodic and constant rains. In 150th day, a short interval of drought occurred, which apparently allowed for reduction in humidity of the residues and consequent increase in electric resistivity. Between days 100 and 130 , occurs the gradual increase in biogas flow, kept with constant flows between $40 \mathrm{~m}^{3} / \mathrm{h}$ and $50 \mathrm{~m}^{3} / \mathrm{h}$ until the end of the monitoring period (Fig. 4).

Although pluviosity in the period is characterized by relatively constant rains between days 100 and 340, with two intervals of drought between days 60 and 100 and days 340 and 350, there were few reflexes in the production of biogas for the period, kept relatively constant and with slight decline in initial moments of drought periods.

The resistivity readings were not directly related to the biogas flows related to drain 5. Readings near drain 28 presented a distinct pattern and average flows much higher to those obtained for drain 5 (Fig. 4).

During the first 60 days of monitoring occur the highest flows of biogas, which increase progressively up to $117 \mathrm{~m}^{3} / \mathrm{h}$ at the end of this period, coinciding with the beginning of the first drought. This interval is characterized by the increase in electric resistivity, with extremes of $350 \Omega . m$ coinciding with the maximum production of biogas, indicative of correlation between the parameters.

From 60th day on, there is a concurring decrease in biogas flow and electric resistivity until approximately 80 days. The interval of low biogas production $\left(70 \mathrm{~m}^{3} / \mathrm{h}\right)$ coincides with the first drought.

Besides the presence of biogas, the electrical resistivity is also sensitive to changes in humidity of the waste. In this sense, it would be expected that in periods of drought there would occur increase in electrical resistivity, while during the rains these values would be reduced. However, the data indicate otherwise, i.e. drop in resistivity with the starting of the first drought.

The lag between the first drought (days 60 and 100), and the period of low resistivity values (days 100 and 140), may be indicative that the rainwater does not reach the waste immediately in this 

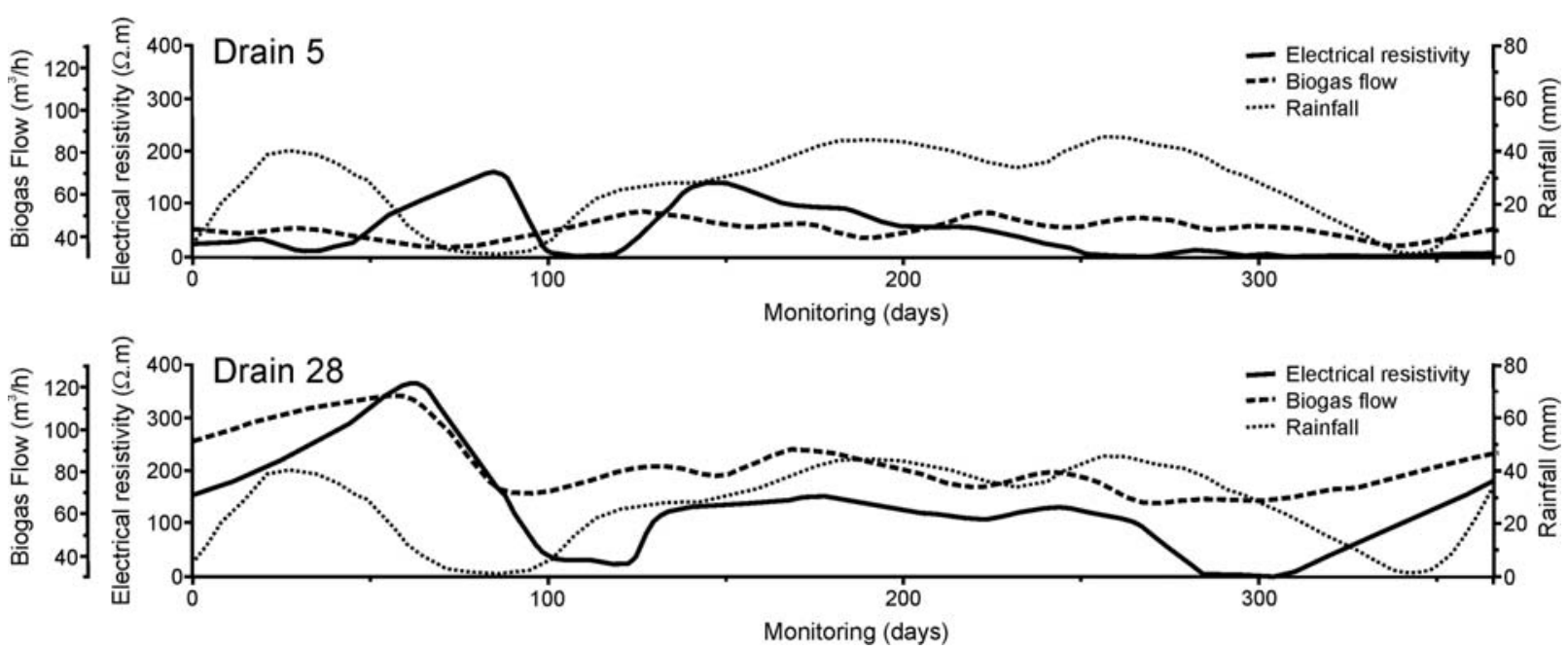

Figure 4 - Electric resistivity, biogas flow and rainfall for the drain 5 (above) and for the drain 28 (below).

area. The routine operation of the landfill consists of launching, spreading and covering the waste with clay soil from the excavation of the packaging cell. It is likely that an average lag of 40th day between rainfall and decrease in resistivity corresponds to infiltration of rainwater in the clay soil covering the waste without fractures (Fig. 4).

From 100th day occurs the onset of rains and gradual increase in biogas production, which passes from $70 \mathrm{~m}^{3} / \mathrm{h}$ to $80 \mathrm{~m}^{3} / \mathrm{h}$, kept constant for 280th day. This beginning corresponds to an increase in resistivity in the readings near the drain 28 for average values of $120 \Omega$.m, also remained constant up to 280th day. This period is characterized by frequent rainfall and with an average between $30 \mathrm{~mm}$ and $40 \mathrm{~mm}$.

Between days 280 and 325 there is a fall in biogas flow, maintained at an average of $70 \mathrm{~m}^{3} / \mathrm{h}$. Meanwhile, the resistivity is reduced to near zero, until the concomitant increase in flow and resistivity from 325th day to the end of the monitoring period.

\section{CONCLUSIONS}

Given the proximity of drains and the presence of a single rainfall scheme for both areas it is possible to associate differences in flow rates of biogas to the availability of organic matter able to degradation. The low flow in the drain 5 can be attributed to the relative scarcity of organic matter consumed during the 5 years of disposal preceding the waste monitoring. In contrast, the beginning of the experiment near the drain 28 coincides with the three months of blocking the area to receive the waste, that is, high availability of materials capable of degradation as reflected in the relatively high production of biogas.
Biogas production in the drain 5 was relatively constant over the period of 1 year with small variations possibly related to rainfall. The resistivity measurements were not directly or indirectly correlated to the flow of biogas. It is possible that the data acquisition device is insensitive to biogas production in small quantities, because of the distance between sensors adopted $(40 \mathrm{~cm})$, which determines factors such as resolution and area of influence of the measures.

The flow rates achieved for the drain 28 were highly variable in the first 90 days of measurements and relatively constant until the end of monitoring. This initial period is characterized by steady increase in flow up to 60 days with a maximum of $117 \mathrm{~m}^{3} / \mathrm{h}$, followed by a decline in production. This pattern is accompanied by resistivity values, with a gradual increase up to 60 days and maximum of $350 \Omega . m$.

Besides the presence of biogas, the electrical resistivity is also sensitive to changes in humidity of the waste in an inverse relationship, i.e., decrease in resistivity with increasing humidity. The lag time between rainfall and infiltration time in coverage soil may explain differences between 60 and 100 days, where the dry season is characterized by lower resistivity values. The slow infiltration of rain provided the decrease in resistivity of the period, with consequences for the production of biogas.

The resistivity measurements for the region of drain 28 showed variations proportional to the variations of biogas flow within 1 year of monitoring, indicative of relative sensitivity of the parameter electrical resistivity and of the data acquisition device at an area of high biogas production with seasonal variations related to flow influenced by rainfall. 


\section{REFERENCES}

ABEM. 2009. Terrameter SAS 4000/SAS 1000 - Instruction Manual. ABEM, Sweden, $97 \mathrm{pp}$.

ANTONIO SM 2012. Análise da variação da vazão e da concentração do metano presentes nos gases gerados no aterro sanitário de Rio Claro SP. Monograph on Environmental Engineering (Graduation). Universidade Estadual Paulista. São Paulo, Brazil, 61 pp.

ASQUITH GB \& GIBSON CR. 1982. Basic Well Log Analysis for Geologists. American Association of Petroleum Geologists, 0klahoma, 234 pp.

BELMONTE-JIMÉNEZ S, JIMENEZ-CASTAÑEDA ME, PÉREZ-FLORES MA, CAMPOS-ENRÍQUEZ J, REYES-LÓPEZ JA \& SALAZAR-PEÑA L. 2012. Characterization of a leachate contaminated site integrating geophysical and hydrogeological information. Geofísica Internacional, 51(4): 309-321.

CHRISTENSEN TH, KJELDSEN P, ALBRECHTSEN HJ, HERON G, NIELSEN PH, BJERG PL \& HOLM PE. 1994. Attenuation of landfill leachate pollutants in aquifers. Critical Review in Environmental Science and Technology, 24: 119-202.

ELLIS DV \& SINGER JM. 2008. Well Logging for Earth Scientists. Springer, Netherlands, $699 \mathrm{pp}$.

FARQUHAR GJ \& ROVERS FA. 1973. Gas production during refuse decomposition. Water, Air and Soil Pollution, 2(10): 483-499.

GEORGAKI I, SOUPIOS P, SAKKAS N, VERVERIDIS F, TRANTAS E, VALLIANATOSF \& MANIOS T. 2008. Evaluating the use of electrical resistivity imaging technique for improving $\mathrm{CH}_{4}$ and $\mathrm{CO}_{2}$ emission rate estimations in landfills. Science of the Total Environment, 389(2-3): 522-531.

KEARY P, BROOKS M \& HILL I. 2002. An Introduction to Geophysical Exploration. Blackwell Science, London, 262 pp.

KELLER GV \& FRISCHKNECHT FC. 1966. Electrical methods in geophysical prospecting. Pergamon Press, New York, 562 pp.
MEJU MA. 2000. Geoelectrical investigation of old/abandoned, covered landfill sites in urban areas: model developmentwith a genetic diagnosis approach. Journal of Applied Geophysics, 44: 115-150.

MILSOM J \& ERIKSEN A. 2011. Field Geophysics. John Wiley \& Sons. Oxford, $297 \mathrm{pp}$.

MOREIRA CA, BRAGA ACO, GODOY LH \& SARDINHA DS. 2013. Relationship between age of waste and natural electric potential generation in Sanitary Landfill. Geofísica Internacional, 52(4): 375-383.

MOREIRA C, CASTRO M, GONSALEZ A, CAVALLARI F, MUNHOZ T \& PEREIRA A. 2014. Comparative analysis between biogas flow in landfill and electrical resistivity tomography in Rio Claro City, Brazil. Journal of Geological Research, article ID 845906, 7 pp.

MOTA R, MONTEIRO SANTOS FA, MATEUS A, MARQUES FO, GONÇALVES MA, FIGUEIRAS J \& AMARAL H. 2004. Granite fracturing and incipient pollution beneath a recent landfill facility as detected by geoelectrical surveys. Journal of Applied Geophysics, 57: 11-22.

OMOLAYO D \& TOPE FJ. 2014. 2D Electrical Imaging Surveys for Leachate Plume Migration at an Old Dump Site in Ibadan South Western Nigeria: A Case Study. International Journal of Geophysics, article ID 879530, 6 pp.

ROSQVIST H, LEROUX, V, DAHLIN T, SVENSSON, M, LINDSJÖO M, MANSSON C \& JOHANSSON S. 2011. Mapping landfill gas migration using resistivity monitoring. Waste and Resource Management, (1): 315.

TELFORD WM, GELDART LP \& SHERIFF RE. 2004. Applied Geophysics. Cambridge University Press, New York, 774 pp.

THEMELIS NJ \& ULLOA PA. 2007. Methane generation in landfills. Renewable Energy, 32: 1243-1257.

\section{NOTES ABOUT THE AUTHORS}

César Augusto Moreira. Geologist by Universidade Estadual Paulista - UNESP (2003), Master (2005) and Doctor in Geoscience by IGCE/UNESP (2009). Experience in Applied Geophysics, with emphasis on Electrical methods (DC Resistivity, IP, SP) and Electromagnetic methods (FEM, TEM, GPR) applied in Environmental and Mineral Prospecting studies. Assistant Doctor Professor in Applied Geology Department, Geoscience and Exact Science Institute, Universidade Estadual Paulista UNESP - Rio Claro Campus. Practice areas: applied geophysics in mineral exploration, hydrogeology, geotechnical and environmental studies.

Marcus Cesar Avezum Alves de Castro. Mechanical Engineering by São Carlos Engineering School - Universidade de São Paulo (EESC-USP). Master and Doctor in Hydraulic and Sanitation by Universidade de São Paulo. Assistant Doctor Professor in Applied Geology Department, Geoscience and Exact Science Institute, Universidade Estadual Paulista - UNESP - Rio Claro Campus. Practice areas: solid waste management (home and health services), treatment of the landfill leachate, energy generation by solid waste.

Leonardo Paioli Carrazza. Geologist by Universidade Estadual Paulista - UNESP (2013). Masters student Geoscience and Environmental Science Post-graduation Program, Geoscience and Exact Science Institute, Universidade Estadual Paulista - UNESP - Rio Claro Campus. Practice areas: applied geophysics in geotechnical studies. 
Fernanda Cavallari. Environmental Engineering by Universidade Estadual Paulista - UNESP (2014). Masters student Geoscience and Environmental Science Post-graduation Program, Geoscience and Exact Science Institute, Universidade Estadual Paulista - UNESP - Rio Claro Campus. Practice areas: applied geophysics in environmental studies.

Livia Portes Innocente Helene. Environmental Engineering by Universidade Estadual Paulista - UNESP (2014). Masters student Geoscience and Environmental Science Post-graduation Program, Geoscience and Exact Science Institute, Universidade Estadual Paulista - UNESP - Rio Claro Campus. Practice areas: applied geophysics in environmental studies.

Fabio Braz Machado. Geologist by Universidade Estadual Paulista - UNESP (2003), Master (2005) and Doctor in Geoscience by IGCE/UNESP (2009). Post-doctoral (2011). President of Brazilian Geological Society (São Paulo) between 2004-2009. Adjunct professor II in Universidade Federal de São Paulo (UNIFESP) - Diadema Campus. Practice areas: petrology of magmatic rocks, vulcanism, large igneous province, geochemistry rocks/mantle, mineralogy, Paraná basin and basalts. 